\title{
Aktivitas Sitotoksik Ekstrak Heksan, Ekstrak Etil Asetat, Ekstrak Etanol Buah Mengkudu (Morinda citrifolia $L$ ) Terhadap Sel T47D
}

\section{Cytotoxic effect of hexane extract, ethyl acetate extract and ethanol extract of Morinda citrifolia L on T47D cells}

\author{
Maryati Maryati*, Ahmad Novian Nur Anas, Muhammad Nur Khairudin \\ Fakultas Farmasi ,Universitas Muhammadiyah Surakarta, Jalan A. Yani, Tromol Pos 1, Pabelan Kartasura, \\ Surakarta \\ E-mail: maryati@ums.ac.id
}

Received: 27 April 2020; Accepted: 22 Juni 2020; Published: 30 Juni 2020

\begin{abstract}
Abstrak
Buah mengkudu (Morinda citrifolia L) adalah salah satu bahan alam yang biasa digunakan sebagai obat tradisional untuk mengatasi beragam penyakit salah satunya kanker. Buah mengkudu diketahui mengandung senyawa antrakinon dan kumarin yang mempunyai efek antikanker. Penelitian ini bertujuan untuk mengetahui efek sitotoksik ekstrak n-heksan, etil asetat dan etanol buah mengkudu dan untuk mengetahui keberadaan senyawa antrakinon dan kumarin dalam ekstrak tersebut. Ekstraksi dilakukan dengan metode maserasi bertingkat dengan pelarut n-heksan, dilanjutkan dengan etil asetat dan etanol. Uji efek sitotoksik terhadap sel T47D dilakukan dengan metode MTT. Identifikasi senyawa antrakinon dan kumarin dilakukan dengan metode kromatografi lapis tipis. Hasil uji menunjukkan ekstrak n-heksan buah mengkudu memiliki efek sitotoksik medium dengan nilai $\mathrm{IC}_{50}$ rata-rata sebesar $582,13 \pm 61,64 \mu \mathrm{g} / \mathrm{mL}$, sedangkan ekstrak etanol dan etil asetat buah mengkudu tidak memiliki efek sitotoksik terhadap sel T47D. Hasil KLT menunjukkan ekstrak n-heksan buah mengkudu mengandung senyawa antrakinon dan kumarin . Kata Kunci: Morinda citrifolia L, sitotoksik, kumarin, antrakinon
\end{abstract}

\begin{abstract}
Noni fruit (Morinda citrifolia $\mathrm{L}$ ) is one of the natural ingredients commonly used as traditional medicine to overcome various diseases, such as cancer. Noni fruit contains anthraquinone and coumarin which have anticancer effects. This study aims to determine the cytotoxic effects of $n$-hexane, ethyl acetate and ethanol extract of noni fruit and to determine the presence of anthraquinone and coumarin in the extract. Extraction was carried out by maceration method using $n$-hexane, followed by ethylacetate and ethanol. The cytotoxic activity on T47D cells was carried out by the MTT method. The presence of anthraquinone and coumarin was identified using thin layer chromatography (TLC). Results showed that $n$-hexane extract had moderate cytotoxic effect on T47D cells with $\mathrm{IC}_{50}$ value of $582.13 \pm 61.64 \mu \mathrm{g} / \mathrm{mL}$, while the ethanol and ethylacetate extract did not have cytotoxic effect on T47D cells. TLC results indicated that $\mathrm{n}$-hexane extract of noni fruit contains anthraquinone and coumarin.
\end{abstract}

Keywords: Morinda citrifolia L, cytotoxic, coumarine, anthraquinon

\section{PENDAHULUAN}

Kanker merupakan sekelompok sel yang abnormal di dalam tubuh yang menyebabkan pertumbuhan sel menjadi tidak terkendali. Kanker disebabkan oleh beberapa faktor di antaranya sosial, budaya, gaya hidup, hormon dan faktor genetik (Hejmadi, 2010). Pada tahun 2014 terdapat 92.200 perempuan yang meninggal karena kanker. Persentase tertinggi penyebab kematiannya yaitu kanker payudara sebesar 21,4\% (World Health Organization, 2014).

Saat ini penggunaan kemoterapi pada penderita kanker masih memiliki beberapa kelemahan dapat merusak sel-sel normal dalam tubuh, efek samping seperti kelelahan, mual muntah, kerontokan rambut. Dengan alasan tersebut maka perlu dicari obat yang 
selektif membunuh sel kanker dan mempunyai efek samping yang lebih kecil (Aslam et al., 2014). Upaya tersebut dapat dilakukan dengan eksplorasi bahan alam, salah satunya buah mengkudu. Buah mengkudu telah digunakan sebagai obat tradisional untuk pengobatan beberapa penyakit seperti antioksidan, antiinflamas i, analgesik, hipertensi, antikanker (Kaur et al., 2018) dan immunomodulator (Almeida-Souza, 2018).

Penelitian menyebutkan bahwa ekstrak etil asetat akar mengkudu mengandung senyawa damnacanthal suatu antrakinon yang memiliki aktivitas antikanker pada sel MCF7 dengan nilai $\mathrm{IC}_{50}$ sebesar $8,2 \mu \mathrm{g} / \mathrm{mL}$ (Aziz et al., 2014). Penelitian lainnya menyebutkan ekstrak etanol daun mengkudu memiliki aktivitas sitotoksik pada sel kanker murine WEHI-3B leukemia dengan nilai $\mathrm{IC}_{50} 17$ $\mu \mathrm{g} / \mathrm{mL}$. Senyawa yang bertanggung jawab terhadap aktivitas sitotoksik itu adalah damnacanthal dan scopoletin (Ahmadi et al., 2017). Damnacanthal pada mengkudu terbukti mempunyai aktivitas sitotoksis pada sel kanker kolon (Nualsanit et al., 2012) Penelitian lain menyebutkan bahwa pada akar tanaman mengkudu mengandung senyawa antrakinon damnacanthal dan nondamnacanthal yang mempunyai efek sitotoksik dan menyebabkan cell cycle arrest pada sel H400 oral cancer cell (Shaghayegh et al., 2016). Kedua senyawa ini terbukti dapat menghambat proliferasi dan menginduksi apoptosis dari sel H400 OSCC (Oral Squamosa Cell Carcinoma) (Shaghayegh et al., 2017). Buah mengkudu juga diketahui mengandung senyawa scopoletin. Scopoletin merupakan senyawa kumarin yang telah dibuktikan secara ilmiah memiliki aktivitas antikanker, antioksidan, antidiabetes tipe 2, antihipertensi dan antibakteri (Wijaya et al., 2014). Sejauh pengetahuan peneliti belum pernah dilaporkan efek sitotoksik buah mengkudu terhadap sel kanker T47D, karena itu peneliti tertarik untuk melakukan penelitian tentang aktivitas sitotoksik buah mengkudu terhadap sel kanker payudara T47D. Pada penelitian ini akan diuji aktivitas sitotoksik ekstrak heksana, ekstrak etil asetat dan ekstrak etanol buah mengkudu terhadap sel kanker T47D.

\section{METODE PENELITIAN \\ Alat dan Bahan}

Alat yang digunakan untuk melakukan penelitian ini yaitu rotary evaporator (Heidolph), waterbath (Memmert), almari pengering, inkubator $\mathrm{CO}_{2}$ (Binder), 96-well plate, cytotoxic safety cabinet (ESCO), ELISA reader (Elx800 Bio Tech), vortexs, sonicator, mikroskop (Everted), neraca analitik (Ohaus), plat KLT, haemositometer (Neubauer), kondensor, lampu UV portable.

Bahan yang digunakan: buah mengkudu, etanol 96\%, etil asetat, n-heksan, air, sel T47D, RPMI (Rosewell Park Memorial Institute) 1640, NaHCO3, DMSO, $\mathrm{HCl} 1 \mathrm{M}$, $\mathrm{NaOH} 1 \mathrm{M}$, FBS 10\%, HEPES, fungison $1 \%$, antibiotik penisilin-streptomisin 3\%, alkohol $80 \%$, tripsin $0,025 \%$, PBS (Phosphat Buffered Saline), larutan MTT (3-(4,5dimetiltiazol-2-il) difenil tetrazolium bromida) 0,5\%, larutan SDS (Sodium Dodesil Sulfat), silika gel GF254, pereaksi dragrendorff, $\mathrm{FeCl}_{3}$, pereaksi vanillin $\mathrm{HCl}$, pereaksi vanilin asam sulfat, dan pereaksi Liebermann-Burchard.

\section{Metode Uji}

\section{Ekstraksi}

Buah mengkudu dipotong tipis-tip is, kemudian dikeringkan dengan menggunakan oven selama 72 jam pada suhu $50^{\circ} \mathrm{C}$. Sebanyak $200 \mathrm{mg}$ simplisia selanjutnya diekstraksi dengan metode maserasi bertingkat dengan pelarut heksana, etil asetat dan etanol. Maserasi bertingkat dilakukan dengan kombinasi digesti dan refluks selama 1-2 jam pada suhu $40-60^{\circ} \mathrm{C}$. Maserasi bertingkat dilakukan per pelarut hingga filtrat tidak mengandung senyawa terlarut lagi. Hal ini dicek dengan cara menotolkan filtrat dalam lempeng KLT dan diamati di bawah lampu UV $254 \mathrm{~nm}$ dan $366 \mathrm{~nm}$, terlihat tidak adanya pemadaman atau fluorosensi. Setiap kali maserasi menggunakan $300 \mathrm{~mL}$ pelarut. 
Hasil maserasi disaring dengan kertas saring, selanjutnya diuapkan menggunakan rotary evaporator pada suhu $50^{\circ} \mathrm{C}$ dilakukan sampai mendapatkan ekstrak kental (Saifudin, 2014). Analisis kandungan senyawa

Analisis kandungan senyawa buah mengkudu dilakukan dengan kromatografi lapis tipis dengan fase gerak n-heksan dan etil asetat $(93: 7 \mathrm{v} / \mathrm{v})$ dan fase diam silika gel $\mathrm{GF}_{254}$. Senyawa yang akan dideteksi dari ekstrak heksana, etil asetat dan etanol buah mengkudu adalah skopolatin suatu kumarin dan damnacanthal suatu antrakinon. Keberadaan kumarin dan antrakinon dideteksi dengan menggunakan menggunakan reagen semprot $\mathrm{KOH}$-etanolik, dan diamati di bawah sinar $\mathrm{UV}_{254}$ dan $\mathrm{UV}_{366} \mathrm{~nm}$ (Oktaviani et al., 2011). Skopoletin (kumarin) setelah dilakukan penyemprotan reagen $\mathrm{KOH}-$ etanolik akan terbentuk warna biru (Bhatt et al., 2011). Damnacanthal (antrakinon) bila disemprot dengan reagen $\mathrm{KOH}$ etanolik akan menghasilkan warna merah (Shami., 2015)

\section{Uji sitotoksik}

\section{Pembuatan larutan stok sampel}

Ekstrak heksan, etil asetat dan etanol buah mengkudu ditimbang kurang lebih 10 mg dan dilarutkan dengan $100 \mu \mathrm{L}$ DMSO dan menggunakan bantuan vortex kemudian ditambahkan media hingga $1000 \mu \mathrm{L}$. Selanjutnya dibuat 5 seri konsentrasi sampel $(25 \mu \mathrm{g} / \mathrm{mL}, \quad 25 \mu \mathrm{g} / \mathrm{mL}, \quad 100 \mu \mathrm{g} / \mathrm{mL}, \quad 200$ $\mu \mathrm{g} / \mathrm{mL}$ dan $400 \mu \mathrm{g} / \mathrm{mL}$ ).

Uji sitotoksik

Seratus mikroliter suspensi sel T47D dimasukkan dalam 96-well plate dengan kepadatan $10^{4}$. Untuk mengadaptasikan sel, plate diinkubasi selama 24 jam pada inkubator $\mathrm{CO}_{2}$ 5\%. Selanjutnya $100 \mu \mathrm{L}$ sampel ditambahkan dalam sumuran hingga diperoleh konsentrasi akhir sampel 25, 50, 100, 200 dan $400 \mu \mathrm{g} / \mathrm{mL}$. Plate diinkubasi pada suhu $37^{\circ} \mathrm{C}$ dalam inkubator $\mathrm{CO}_{2} 5 \%$ selama 48 jam. Selanjutnya sumuran yang berisi medium dibuang dan dicuci dengan PBS. Larutan MTT 0,5 \% (100 $\mu \mathrm{L})$ ditambahkan ke dalam tiap sumuran dan dïnkubasi pada inkubator $\mathrm{CO} 25 \%$ selama 4 jam pada suhu $37^{\circ} \mathrm{C}$. Reaksi dari sel hidup dan pereaksi MTT akan membentuk formazan (berwarna ungu). Selanjutnya reagen stopper (SDS 10\% $100 \mu \mathrm{L}$ dalam $\mathrm{HCl} 0,01 \quad \mathrm{~N}$ ) ditambahkan pada plate, kemudian plate dibungkus alumunium foil untuk diinkubasi selama 24 jam di tempat gelap pada suhu kamar. Absorbansi dibaca dengan ELISA reader pada panjang gelombang $550 \mathrm{~nm}$. Data absorbansi digunakan untuk menghitung persen sel hidup, selanjutnya untuk menentukan nilai $\mathrm{IC}_{50}$ ekstrak.

\section{Analisis data}

Persentase sel hidup dihitung dari absorbansi yang diperoleh, kemudian dibuat kurva hubungan antara log konsentrasi versus $\%$ sel hidup, kemudian didapat persamaan $\mathrm{y}=$ $\mathrm{bx}+\mathrm{a}$. Perhitungan $\mathrm{IC}_{50}$ dihitung dengan cara mensubtitusi nilai 50 pada $\mathrm{Y}$ sehingga diperoleh nilai $\mathrm{x}$ dan nilai $\mathrm{IC}_{50}$ merupakan antilog x. Rumus perhitungan \% sel hidup sebagai berikut :

1. Jika absorbansi kontrol pelarut sama dengan absorbansi kontrol sel maka perhitungan persentase sel hidup

$$
\begin{aligned}
& \text { Persentase sel hidup } \\
& =\frac{(\text { Abs. perlakuan }- \text { Abs. kontrol media })}{\text { (Abs. kontrol sel - Abs. kontrol media) }} \times 100 \%
\end{aligned}
$$

2. Jika absorbansi kontrol pelarut lebih rendah dari absorbansi kontrol sel maka perhitungan persentase sel hidup dengan rumus berikut:

$$
\begin{aligned}
& \text { Persentase sel hidup } \\
& =\frac{(\text { Abs. perlakuan }- \text { Abs. kontrol media })}{(\text { Abs. kontrol pelarut }- \text { Abs. kontrol media })} \times 100 \%
\end{aligned}
$$

(Cancer Chemoprevention Research Center,

Uji KLT digunakan untuk menganalisi kandungan senyawa yang terdapat pada ekstrak heksana, etil asetat dan etanol buah mengkudu. Bercak yang dihasilkan dihitung dengan menggunakan rumus :

$$
R f=\frac{\text { Jarak elusi zat terlarut }(\mathrm{cm})}{\text { Jarak elusi pelarut }(\mathrm{cm})}
$$


Tabel 1. Hasil analisis senyawa antrakuinon dan kumarin dalam ekstrak n-heksan buah mengkudu menggunakan metode KLT, dengan fase diam silikagel GF254 dan fase gerak heksan:etil asetat $(9: 1 \mathrm{v} / \mathrm{v})$.

\begin{tabular}{|c|c|c|c|c|c|}
\hline \multirow[t]{2}{*}{ NO } & \multirow[t]{2}{*}{$\mathbf{R f}$} & \multirow{2}{*}{$\begin{array}{l}\text { Sinar } \\
\text { Tampak }\end{array}$} & \multirow[t]{2}{*}{ UV366 } & $\begin{array}{l}\text { Reagen Semprot } \\
\text { (KOH etanolik) }\end{array}$ & $\begin{array}{c}\text { Kandungan } \\
\text { Senyawa } \\
\end{array}$ \\
\hline & & & & $\mathrm{UV}_{366}$ & \\
\hline 1 & 0,33 & - & Merah & Merah & Antrakinon \\
\hline 2 & 0,78 & - & biru & Biru & Kumarin \\
\hline
\end{tabular}

Plat KLT disemprotkan beberapa reagen untuk melihat lebih jelas di bawah sinar UV senyawa apa yang terdapat pada bercak kromatogram yang dihasilkan. Reagen semprot tersebut adalah reagen semprot $\mathrm{KOH}$-etanolik untuk mendeteksi senyawa scopoletin yang merupakan golongan kumarin. Warna yang dihasilkan adalah biru (Wagner et al., 1996), dan reagen $\mathrm{KOH} 10 \%$ untuk mendeteksi senyawa damnacanthal yang merupakan senyawa antrakinon. Warna yang dihasilkan adalah merah (Warner et al, 1996).

\section{HASIL DAN PEMBAHASAN}

Pada penelitian ini, ekstraksi dilakukan dengan metode maserasi bertingkat dengan pelarut n-heksan, etil asetat dan etanol. Maserasi bertingkat dilakukan di atas digital hot plate dengan suhu $40-60^{\circ} \mathrm{C}$ dan dibantu dengan magnetic stirrer selama 1 jam. Keuntungan metode maserasi bertingkat yaitu mudah, sederhana, tidak ada gangguan fisik, rendemen yang dihasilkan lebih tinggi dan juga lebih efisien dalam penyarian ekstrak karena adanya bantuan refluks dengan pemanasan pada suhu $40-60^{\circ} \mathrm{C}$. Maserasi bertingkat dimulai dengan pelarut heksan, etil asetat dan terakhir dengan etanol (Saifudin, 2014). Rendemen yang diperoleh adalah $1,57 \%$ untuk ekstrak n-heksan, ekstrak etil asetat $0,82 \%$ dan ekstrak etanol $22,49 \%$.

Identifikasi senyawa antrakinon dan kumarin dilakukan dengan kromatografi lapis tipis dengan fase diam silika gel $\mathrm{GF}_{254}$ dan fase gerak heksan:etil asetat $(90: 10 \mathrm{v} / \mathrm{v})$. Visualisasi senyawa dilakukan dengan reagen semprot $\mathrm{KOH}$ 10\%. Gambar 1 menunjukkan hasil KLT ekstrak etanol mengkudu. Hasil KLT menunjukkan bahwa ekstrak n-heksan buah mengkudu mengandung antrakinon dan kumarin (Tabel 1). Senyawa antrakinon berfluorosensi merah di bawah sinar $\mathrm{UV}_{366}$ $\mathrm{nm}$, sedangkan kumarin berflurosensi biru pada UV $366 \mathrm{~nm}$ (Wagner et al., 1996).

Uji sitotoksik ekstrak terhadap sel T47D dilakukan dengan metode MTT dengan doksorubisin sebagai kontrol positif. Prinsip metode MTT didasarkan pada adanya reduksi garam kuning tetrazolium MTT (3-(4,5-dimetiltiazol-2-il)-2,5difeniltetrazolium bromida) oleh enzim reduktase pada mitokondria sel hidup yang mengubah reagen MTT yang awalnya berwarna kuning menjadi kristal formazan berwarna ungu dan tidak larut dalam air (Doyle and Griffiths, 2000).

Penambahan reagen stopper (SDS 10\% dalam $0,01 \mathrm{~N} \mathrm{HCl}$ ) yang bersifat detergenik dapat menghentikan reaksi enzimatik dari enzim dan melarutkan kristal formazan sehingga bisa dibaca absorbansinya dengan ELISA reader. Intensitas warna ungu yang terbentuk berbanding lurus dengan jumlah sel hidup, sehingga jika intensitas warna ungu semakin besar maka jumlah sel yang hidup semakin banyak (Cancer Chemoprevention Research Center, 2014). Pada uji ini pelarut yang digunakan adalah DMSO (Capriotti et al., 2012). Menurut Purwaningsih (2014) DMSO dengan kadar kurang dari 3\% tidak bersifat toksik atau membunuh sel kanker sehingga dapat digunakan sebagai pelarut pada uji sitotoksik.

Kondisi morfologi sel T47D sebelum diberikan perlakuan terlihat berbentuk 


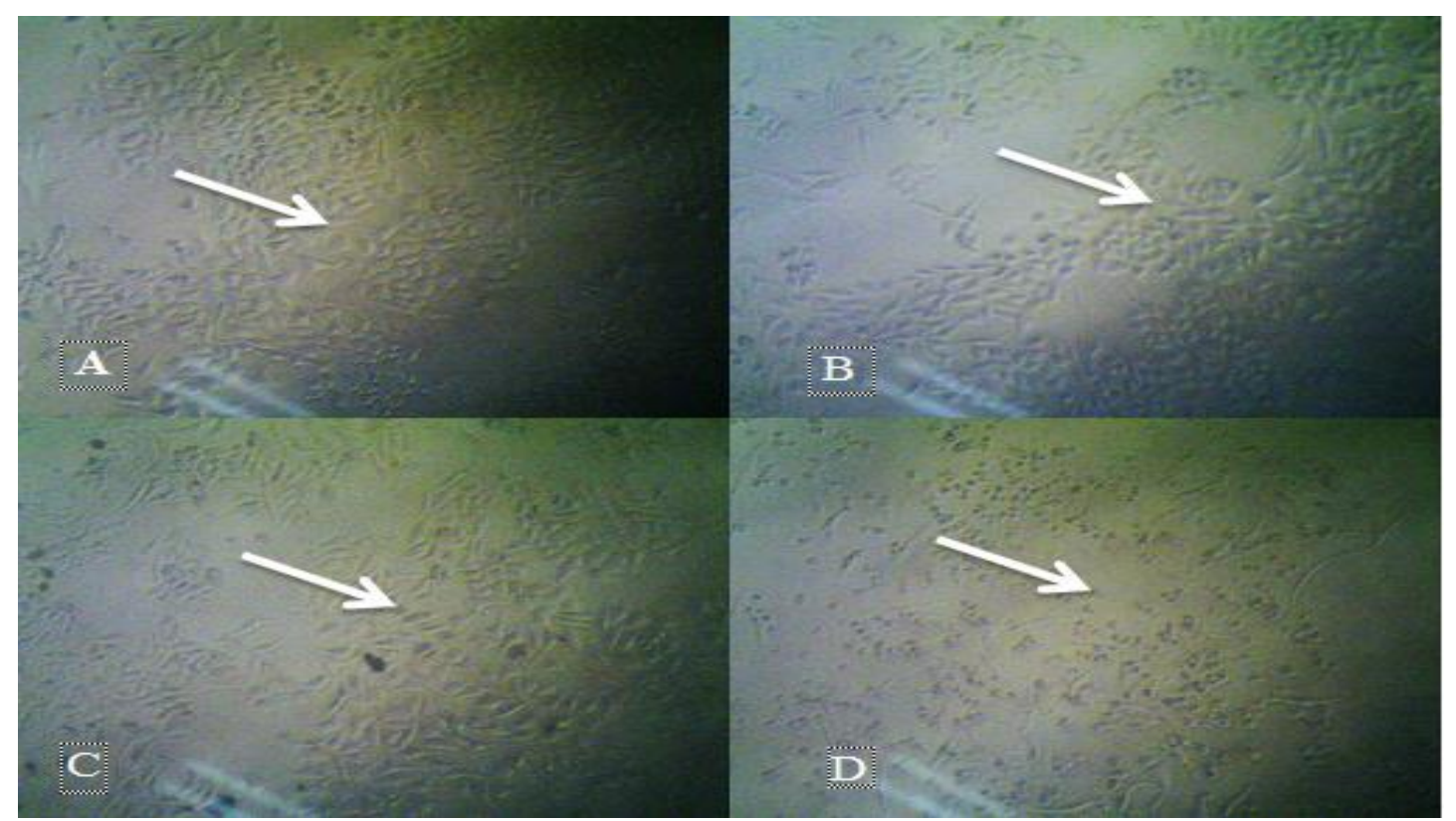

Gambar 1. Sel T47D tanpa perlakuan ekstrak (A), perlakukan dengan ekstrak etanol $800 \mu \mathrm{g} / \mathrm{mL}(\mathrm{B})$, perlakuan dengan ekstrak etil as etat $800 \mu \mathrm{g} / \mathrm{mL}$ (C) dan perlakuan dengan ekstrak $n$-heksan 800 $\mu \mathrm{g} / \mathrm{mL}$ (D)

lonjong (Gambar 1A). Sel tidak mengalami kematian setelah perlakuan ektrak etanol dengan konsentrasi $800 \mu \mathrm{g} / \mathrm{mL}$ ini terlihat dari bentuk sel yang masih lonjong (Gambar 1B). Pada perlakuan ekstrak etil asetat pada konsentrasi tertinggi yang diujikan (800 $\mu \mathrm{g} / \mathrm{mL}$ ) terlihat sedikit sel yang mengalami kematian (Gambar 2C). Perlakuan sel T47D dengan ekstrak $n$-heksan $(800 \mu \mathrm{g} / \mathrm{mL})$ menunjukan adanya perubahan morfologi sel T47D dari bentuk awal lonjong berubah menjadi bintik hitam, ini menandakan bahwa sel menggalami kematian (Gambar 1D.
Hasil uji menunjukkan bahwa ekstrak heksan memiliki aktivitas sitotoksik yang lemah, sedangkan ekstrak etil asetat dan etanol buah mengkudu tidak memilki aktivitas sitotoksik (Tabel 2).

Hasil ini berbeda dari penelitian sebelumnya yang menunjukkan ekstrak etil asetat akar mengkudu dan ekstrak etanol daun mengkudu memiliki efek sitotoksik pada sel MCF-7 dan WEHI-3B leukemia nilai $\mathrm{IC}_{50}$ berturut-turut sebesar $8,2 \mu \mathrm{g} / \mathrm{mL}$ pada dan 17 $\mu \mathrm{g} / \mathrm{mL}$ (Aziz et al., 2014, Ahmadi et al., 2017). Perbedaan ini mungkin disebabkan

Tabel 2. Hasil uji sitotoksik ekstrak $n$-heksan, etil asetat dan etanol buah mengkudu terhadap sel T47D

\begin{tabular}{cccc}
\hline \multirow{2}{*}{$\begin{array}{c}\text { Konsentrasi } \\
(\boldsymbol{\mu g} / \mathbf{m l})\end{array}$} & \multicolumn{3}{c}{ Rata-rata \% sel hidup } \\
\cline { 2 - 4 } & Esktrak Heksan $(\mathbf{X} \pm$ SD) & Ekstrak Etil asetat & Ekstrak Etanol \\
\hline 50 & $119,93 \pm 4,72$ & 126,88 & 125,65 \\
100 & $113,12 \pm 7,29$ & 129,63 & 126,13 \\
200 & $91,21 \pm 9,66$ & 147,58 & 125,26 \\
400 & $59,32 \pm 7,45$ & 168,13 & 111,07 \\
800 & $10,34 \pm 8,97$ & 138,68 & 87,33 \\
\hline $\mathrm{IC}_{50}$ & $582,13 \pm 61,64$ & - & - \\
\hline
\end{tabular}

Catatan: data ekstrak heksan yang ditampilkan berupa rata-rata \pm SD, ekstrak etil as etat dan eks trak etanol pada pengujian pertama tidak menunjukkan adanya aktivitas, sehingga tidak dilakukan replikasi. 
Tabel 3. Hasil uji sitotoksik kontrol positif (doksorubisin)

\begin{tabular}{ccc}
\hline Konsentrasi $(\mu \mathrm{g} / \mathrm{ml})$ & Rata-rata \% sel hidup & IC $_{50}(\mu \mathrm{g} / \mathrm{ml})$ \\
\hline 0,0625 & $125,68 \pm 14,33$ & \\
0,125 & $87,78 \pm 18,60$ & \\
0,25 & $23,14 \pm 11,07$ & 0,29 \\
0,5 & $10,22 \pm 2,13$ & \\
1 & $11,19 \pm 0,16$ & \\
2 & $6,49 \pm 1,65$ & \\
\hline
\end{tabular}

oleh beberapa hal di antaranya jenis sel yang digunakan berbeda dari penelitian sebelumnya. Selain itu bagian tumbuhan yang digunakan juga berbeda sehingga kemungkinan kandungan senyawa kimia juga berbeda. Syarat utama sampel dapat diuji ke kultur sel harus larut dalam media dan kelarutannya dibantu oleh DMSO, pada penelitian ini ekstrak heksan yang agak sukar larut di dalam media dan DMSO, sehingga dibutuhkan waktu 25 menit sonikator dan 30 menit vortex untuk membantu pencampurannya. Hasil kontrol positif (doksorubisin) yang diperoleh dengan menggunakan konsentrasi tertinggi (2\%) diperoleh rata-rata persentase sel hidup sebesar 6,49\%, dan konsentrasi terendah $(0,0625 \%)$ rata-rata persentase sel hidup yang diperoleh sebesar $125,68 \%$ dengan nilai $\mathrm{IC}_{50}$ $0,3 \mu \mathrm{g} / \mathrm{mL}$ (Tabel 3). Efek sitotoksik suatu ekstrak dikategorikan berpotensi sitotoksik tinggi jika $\mathrm{IC}_{50}<100 \mu \mathrm{g} / \mathrm{mL}$, medium jika $\mathrm{IC}_{50}$ $100-1000 \mu \mathrm{g} / \mathrm{mL}$, dan tidak berpotensi jika $\mathrm{IC}_{50}>1000 \mu \mathrm{g} / \mathrm{mL}$ (Prayong et al., 2008). Berdasarkan hal tersebut, maka ekstrak etanol dan etil asetat buah mengkudu tidak memiliki aktivitas sitotoksik terhadap sel T47D, dan ekstrak n-heksan memilki aktivitas sitotoksik medium. Kontrol positif dosksorubisin memiliki aktivitas sitotoksik pada sel T47D masuk pada kategori tinggi.

\section{KESIMPULAN}

Ekstrak etil asetat dan ekstrak etanol buah mengkudu tidak memiliki efek sitotoksik terhadap sel T47D. Ekstrak nheksan buah mengkudu memiliki aktivitas sitotoksik medium dengan nilai $\mathrm{IC}_{50}$ rata-rata sebesar 582,13 $\pm 61,64 \mu \mathrm{g} / \mathrm{mL}$. Hasil KLT menunjukkan bahwa esktrak $n$-heksan buah mengkudu mengandung senyawa antrakinon dan kumarin.

\section{Daftar Pustaka}

Ahmadi, H. S. Rahman, R. Rosli, T. A. I. \& S. M., 2017. Morinda citrifolia leaf extract ameliorated leukemia in mice model. J Applied Biotechnology and Bioengineering, 6(2), 249-255. https://doi.org/10.15406/jabb.2017.02.00052

Almeida-Souza, F., Reis deOliveira, A.L., Abreu-Silva A.L., Calabrese, K.S., 2018. In vitro activity of Morinda citrifolia Linn. fruit juice against the axenic amastigote form of Leishmania amazonensis and its hydrogen peroxide induction capacity in BALB/c peritoneal macrophages. BMC Res Notes, 11:492.

Aslam, M. S., Naveed, S., Ahmed, A., Abbas, Z., Gull, I., Athar, M. A., 2014. Side effects of chemotherapy in cancer patients and evaluation of patients opinion about starvation based differential chemotherapy. Journal of Cancer Therapy, 5, 817-822.

Aziz, M.Y.A., Omar, A.R., Subramani, T., Yeap, S.K., Ho, W.Y., Ismail, N.H., Ahmad, S., and Alitheen, N.B., 2014. Damnacanthal is a potent inducer of apoptosis with anticancer 
activity by stimulating p53 and p21 genes in MCF-7 breast cancer cells, Oncology Letters, 7 (5), 1479-1484.

Cancer Chemoprevention Research Center, 2014, Protokol uji sitotoksik, Terdapat di http://ccrc.farmasi.ugm.ac.id/?page_id=240 [Diakses pada 8 Januari 2019].

Capriotti, K., Capriotti, J. A., 2012. Dimethyl sulfoxide history, chemistry, and clinical utility in dermatology. The Journal of Clinical and Aesthetic, 5 (9), 24-26.

Doyle, A. and Griffiths, J.B., 2000. Cell and tissue culture for medicina research. New York: John Willey and Sons Ltd.

Hejmadi., 2010. Introduction to Cancer Biology, $2^{\text {nd }}$ Edition, Penerbit buku kedokteran EGC, Jakarta.

Kaur, H., Nisha, G., Ruth, G., 2018. The noni fruit (Morinda citrifolia L.): a systematic review on anticancer potential and other health beneficial pharmacological activities. Journal of Medicinal Plants Studies; 6(2): 86-93

Nualsanit, T., Rojanapanthu, P., Gritsanapan, W., 2012. Damnacanthal, a noni component, exhibits antitumorigenic activity in human colorectal cancer cells. J Nutr Biochem, 23, 915-23.

Prayong, P., Barusrux, S., and Weerapreeyakul, N., 2008. Cytotoxic activity screening of some indigenous thai plants. Fitoterapia, 79 (7-8), 598-601. Terdapat di: http://dx.doi.org/10.1016/j.fitote.2008.06.007.

Saifudin, A., 2014. Senyawa alam metabolit sekunder teori, konsep, dan teknik pemurnian, Yogyakarta: Deepublish.

Shaghayegh, G., Alabsi A.M., Ali-Saeed R., Ali A.M., Vincent-Chong V.K., Zain R.B., 2016. Cell cycle arrest and mechanism of apoptosis induction in $\mathrm{H} 400$ oral cancer cells in response to damnacanthal and nordamnacanthal isolated from Morinda citrifolia. Cytotechnology, 69, pp.1999-2013

Shaghayegh, G., Alabsi, A.M., Ali-Saeed, R., Ali, A.M., Vincent-Chong, V.K., Ismail, N.H., Choon, Y.F., Zain, R.B., 2017. Effects of damnacanthal and nordamnacanthal on proliferation, apoptosis, and migration of oral squamous cell carcinoma cells. Asian Pacific Journal of Cancer Prevention, Vol 18, pp. 3333-3341.

Wagner, H., and Bladt, S., 1996. Plant drug analysis-a thin layer chromatography atlas (2nd ed), Springer, German.

Wijaya, H., Ramadhan, D., Has, N. and Febriyanti E., 2014. Identifikasi kandungan skopoletin dalam berbagai jenis. Warta IHP/Journal of Agro-based Industry, 31 (1), 11-15.

World Health Organization, 2014. Cancer country profiles: Indonesia, cancer country profiles. 